\title{
Occurrence of lysozyme in the eggs of coho salmon Oncorhynchus kisutch
}

\author{
A. N. Yousif ${ }^{1}$, L. J. Albright ${ }^{1}$, T. P. T. Evelyn ${ }^{2}$ \\ ${ }^{1}$ Institute of Aquaculture Research, Department of Biological Sciences, Simon Fraser University, Burnaby, British Columbia, \\ Canada V5A 1S6 \\ ${ }^{2}$ Department of Fisheries and Oceans, Pacific Biological Station, Nanaimo, British Columbia, Canada V9R 5 K6
}

\begin{abstract}
The occurrence of lysozyme in the eggs of coho salmon Oncorhynchus kisutch is reported for the first time. The eggs were shown to contain high levels of the enzyme, the concentration in the yolk being $1900 \mu \mathrm{g} \mathrm{ml}^{-1}$. Purification of the enzyme was achieved using chitin-coated cellulose and gel filtration. Only one active molecule was isolated and it was shown by SDS-PAGE to have a molecular weight of $14.5 \mathrm{kD}$. Similar levels of lysozyme were found in the eggs of 2 other species of salmonids also tested. The significance of the egg yolk lysozyme is discussed with respect to its role as a natural defence factor against microorganisms, particularly bacteria.
\end{abstract}

\section{INTRODUCTION}

Lysozyme catalyzes the hydrolysis of a structurally important linkage of the peptidoglycan in the cell wall of bacteria, thus solubilizing this complex polymeric substance. The linkage cleaved by the enzyme is the glycosidic bond between the $\mathrm{C}-1$ of $\mathrm{N}$-acetylmuramic acid and the $\mathrm{C}-4$ of $\mathrm{N}$-acetylglucosamine. This linkage is found in most bacterial cell walls (Salton 1957).

Lysozyme from vertebrates has been investigated extensively (Imoto et al. 1972, Osserman et al. 1974). However, birds and mammals have been the source of the enzyme for most studies. Lysozyme has also been detected in tissues of different marine fishes (Sankaran \& Gurnani 1972, Fange et al. 1976, Fletcher \& White 1976), and recently, it was reported to occur in the kidney and digestive tissues of rainbow trout Oncorhynchus mykiss (Lindsay 1986, Grinde et al. 1988) and in the kidney tissues of Atlantic salmon Salmo salar (Lie et al. 1989). However, the presence of the enzyme in the eggs of fish has never been reported. This is an important question because the presence of lysozyme in salmonid eggs could help to explain why certain bacterial fish pathogens are not egg-transmitted.

We describe herein the isolation, purification, and partial characterization of a lysozyme from the eggs of coho salmon Oncorhynchus kisutch and the occurrence of the enzyme in the eggs of 2 other species of Pacific salmon also tested, chinook salmon $O$. tshawytscha and rainbow trout $O$. mykiss.

\section{MATERIALS AND METHODS}

Source of material. Unfertilized, non-water-hardened eggs were obtained from ripe, apparently healthy coho salmon females $(n=7)$ that had returned from the sea to spawn in the Capilano River near Vancouver, British Columbia, Canada. The eggs were transported on ice to the laboratory and immediately stored at $-20^{\circ} \mathrm{C}$. Prior to use, one group of eggs was thawed, homogenized in a tissue grinder at room temperature, and the homogenate filtered through cotton cheesecloth. Another group of thawed eggs was transferred onto absorbent pads of filter paper in a petri dish, to drain the coelomic fluid, and the yolk (EY) was removed using a capillary tube. Both the egg homogenate $(E H)$ and the EY were assayed for lysozyme activity by the lysoplate method (Fange et al. 1976, McHenery et al. 1979).

Lysozyme purification. Alkaline chitin was prepared by the method of Imoto et al. (1968) using powdered chitin from crab shells (Sigma). The chitin ( $5 \mathrm{~g}$ ) was soaked in $50 \mathrm{ml}$ of $42 \%(\mathrm{w} / \mathrm{v})$ sodium hydroxide solution at $34^{\circ} \mathrm{C}$ for $3 \mathrm{~h}$ under reduced pressure to remove air bubbles and to allow good penetration of $\mathrm{NaOH}$ solution into the chitin micelles. The suspension was 
filtered with suction and the cake of alkaline chitin mixed with 3.5 times its weight of finely crushed ice. The mixture was kneaded vigorously by pressing the cake against the wall of the beaker with a glass rod until a homogeneous paste was obtained.

Chitin-coated cellulose (cc-cellulose) was prepared using the method of Imoto \& Yagishita (1973). Cellulose powder ( $5 \mathrm{~g}$ Microgranular, Sigma) was mixed with the alkaline chitin cake. Cold distilled water $(80 \mathrm{ml})$ was added slowly with constant stirring followed by $300 \mathrm{ml}$ of $2 \mathrm{M}$ glacial acetic acid. The residue was washed several times with cold distilled water and stored as an aqueous suspension at $4{ }^{\circ} \mathrm{C}$.

Lysozyme was isolated from coho eggs by stirring $120 \mathrm{ml}$ of cc-cellulose and $40 \mathrm{ml}$ of $\mathrm{EH}$ for $1 \mathrm{~h}$ at $4{ }^{\circ} \mathrm{C}$. The mixture was then centrifuged $(5860 \times g$ for 20 min) at $4^{\circ} \mathrm{C}$ and the supernatant discarded. The sedimented material was washed in a Buchner funnel with 5 volumes of $0.02 \mathrm{M}$ phosphate buffer $\mathrm{pH} 6.8$ containing $0.5 \mathrm{M} \mathrm{NaCl}$ and the washings discarded. The enzyme was eluted by washing the matrix with 2 volumes of $0.1 \mathrm{M}$ glacial acetic acid. The filtered eluate was dialysed against distilled water $(48 \mathrm{~h})$ which removed unwanted water-insoluble egg yolk proteins, leaving behind the water-soluble lysozyme. The water-soluble fraction was then dialysed against $0.06 \mathrm{M}$ phosphate buffer pH 6.0 containing $0.02 \mathrm{M}$ $\mathrm{NaCl}(48 \mathrm{~h})$ at $4{ }^{\circ} \mathrm{C}$, and the small amount of precipitate that developed was removed by centrifugation $\left(5860 \times g\right.$ for $20 \mathrm{~min}$ ) at $4{ }^{\circ} \mathrm{C}$. The supernatant (partially purified lysozyme $=$ PPL) was stored at $4{ }^{\circ} \mathrm{C}$ until used in gel filtration.

Gel filtration. One ml of PPL was applied to a column $(25 \times 1.5 \mathrm{~cm})$ of Sephadex G-100 (Pharmacia). The column was equilibrated with $0.06 \mathrm{M}$ phosphate buffer $\mathrm{pH} 6.0$ containing $0.02 \mathrm{M} \mathrm{NaCl}$. The same buffer was employed for elution. Fractions of $0.5 \mathrm{ml}$ each were collected and screened for lysozyme activity by the rapid and sensitive lysoplate method. Total protein was measured spectrophotometrically at $280 \mathrm{~nm}$ using the Absorbance monitor UA-5 (Instrumentation Specialties Co., USA). Lysozyme-containing fractions were pooled, dialysed against distilled water, and freeze-dried. The purity and molecular weight of the isolated lysozyme were determined by sodium dodecyl sulphate polyacrylamide gel elecrophoresis (SDS-PAGE) (Laemmli 1970). In addition, $1.0 \mathrm{ml}$ of PPL was dialysed against $50 \mathrm{mM}$ Tris/ $\mathrm{HCl}$ buffer $\mathrm{pH} 5$, boiled for $20 \mathrm{~min}$ at $100^{\circ} \mathrm{C}$, and the supernatant electrophoresed in SDS polyacrylamide gel.

Heat stability test. The test was performed as described by Lie \& Syed (1986). Briefly, the PPL from the coho salmon eggs was divided into 2 aliquots, one of which was dialysed against $50 \mathrm{mM}$ Tris/ $\mathrm{HCl}$ buffer pH 5, the other being dialysed against the same buffer at $\mathrm{pH}$ 9. Dialysis was performed for $48 \mathrm{~h}$ at $4{ }^{\circ} \mathrm{C}$. The 2 aliquots were heated in glass test tubes in a water bath at $100^{\circ} \mathrm{C}$ for $20 \mathrm{~min}$. Small samples, drawn from each tube before heating and at intervals of $2 \mathrm{~min}$ during heating, were placed on ice before being assayed by the lysoplate method.

Lysoplate. For assay of lysozyme, $20 \mu \mathrm{l}$ aliquots of sample were dispensed into wells $(3.5 \mathrm{~mm}$ dia. $\times 4 \mathrm{~mm}$ deep) cut into $0.5 \%$ agarose (Type 1 , Sigma) in $15 \mathrm{~cm}$ dia. petri dishes. The agarose contained $0.06 \mathrm{M}$ phosphate buffer $\mathrm{pH} 6.0,0.02 \mathrm{M} \mathrm{NaCl}$, and Micrococcus lysodeikticus $\left(0.6 \mathrm{mg}\right.$ freeze-dried cells $\mathrm{ml}^{-1}$, Sigma). After incubation for $20 \mathrm{~h}$ at room temperature in a humid chamber, the diameters of zones of M. lysodeikticus lysis were measured and compared to those produced by hen egg-white lysozyme (HEWL, Sigma) standards (50 to $2000 \mu \mathrm{g} \mathrm{m}{ }^{-1}$ ) (Fange et al. 1976, McHenery et al. 1979).

Adsorption onto cc-cellulose. To further characterize the isolated enzyme, the following experiment was conducted: to $30 \mathrm{ml}$ of cc-cellulose, $5 \mathrm{ml}$ of PPL (initial activity $=700 \mu \mathrm{g} \mathrm{ml}^{-1}$ ) was added and the reaction mixture was stirred for $90 \mathrm{~min}$ at room temperature. Finally, the suspension was centrifuged $(5860 \times$ $g$ for $20 \mathrm{~min}$ ) and the supernatant assayed for lysozyme activity by the lysoplate method.

\section{RESULTS AND DISCUSSION}

The analysis of homogenized whole specimens of eggs as well as yolk revealed the presence of lysozyme (1900 and $1950 \mu \mathrm{g} \mathrm{mI}^{-1}$ for EY and EH, respectively), and lysoplate results (Fig. 1) are the first unequivocal evidence for the presence of lytic activity due to lysozyme in salmonid eggs. The presence of the enzyme at such concentrations in the eggs of coho salmon was not unique. Yolk samples from chinook salmon Oncorhynchus tshawytscha and rainbow trout O. mykiss were also assayed by the lysoplate method, and the results showed the presence of lysozyme in comparable concentrations to those found in coho eggs: 1900 and $1850 \mu \mathrm{g} \mathrm{ml}^{-1}$ of yolk for chinook salmon and rainbow trout, respectively.

The purified lysozyme from coho salmon eggs satisfied the criteria for 'true' lysozymes proposed by Salton (1957) and Jolles (1969) because it lysed M. lysodeikticus cells (Fig. 1), was readily adsorbed by chitincoated cellulose (Fig, 2), and was a low molecular weight protein (Fig. 3), In addition, the studies on heat stability (Fig. 4) revealed typical lysozyme features: the enzyme was remarkably stable when heated at $100^{\circ} \mathrm{C}$ for $20 \mathrm{~min}$ at acidic $\mathrm{pH}$, but was inactivated under alkaline conditions. The former property of lysozyme may be useful for removing most of the contaminating 


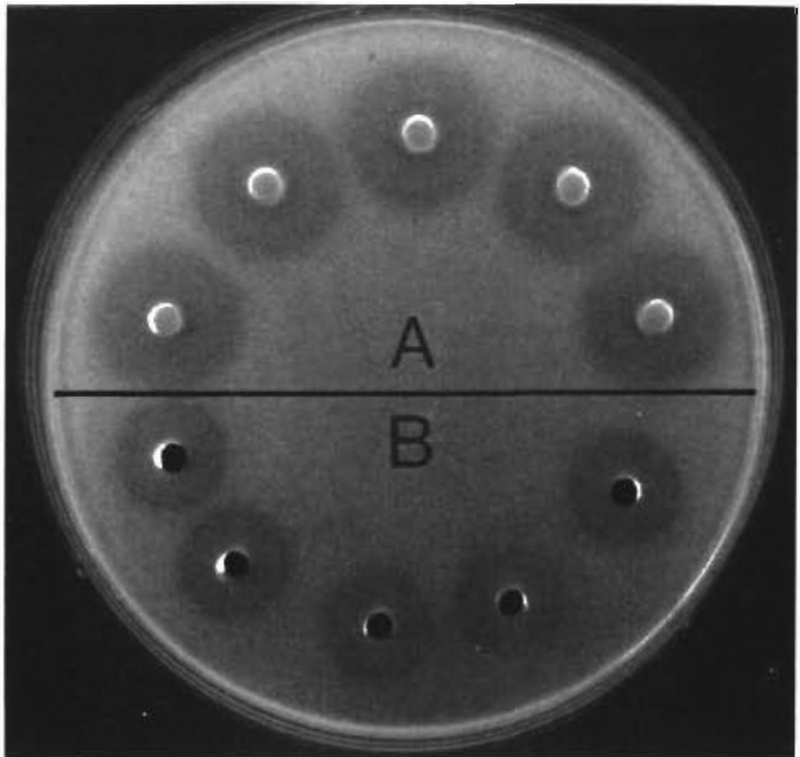

Fig. 1. Oncorhynchus kisutch. Demonstration of lysozyme activity in whole egg homogenate (A), compared with that of twice-crystallized hen's egg-white lysozyme $\left(700 \mu \mathrm{g} \mathrm{ml} \mathrm{m}^{-1}\right)$ (B). Plate assay (lysoplate) method, with heat-killed Micrococcus lysodeikticus incorporated in phosphate-buffered $(\mathrm{pH} 6.0$ ) agarose gel. Samples $(20 \mu \mathrm{l})$ were placed in wells, $3.5 \mathrm{~mm}$ in diameter and $4 \mathrm{~mm}$ deep, and the plate was photographed after 24 h at 20 to $22^{\circ} \mathrm{C}$. Dark zones around sample wells are zones of clearing due to bacterial lysis

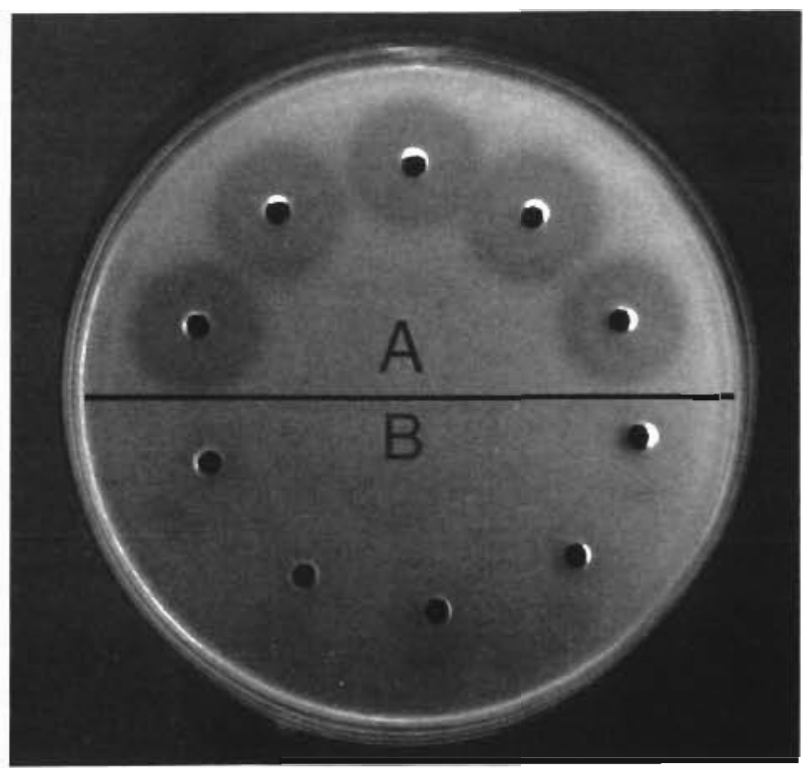

Fig. 2. Oncorhynchus kisutch. Ability of chitin-coated cellulose to adsorb coho egg lysozyme. Lytic activity due to partially purified lysozyme (A) from the eggs of coho salmon and (B) from the same preparation after treatment with cc-cellulose. Plate assay (lysoplate) method, with heat-killed Micrococcus lysodeikticus incorporated in phosphate-buffered $(\mathrm{pH}$ 6.0) agarose gel. Samples $(20 \mu l)$ were placed in wells, $3.5 \mathrm{~mm}$ in diameter and $4 \mathrm{~mm}$ deep, and the plate was photographed after $24 \mathrm{~h}$ at 20 to $22^{\circ} \mathrm{C}$. Dark zones around sample wells are zones of clearing due to bacterial lysis

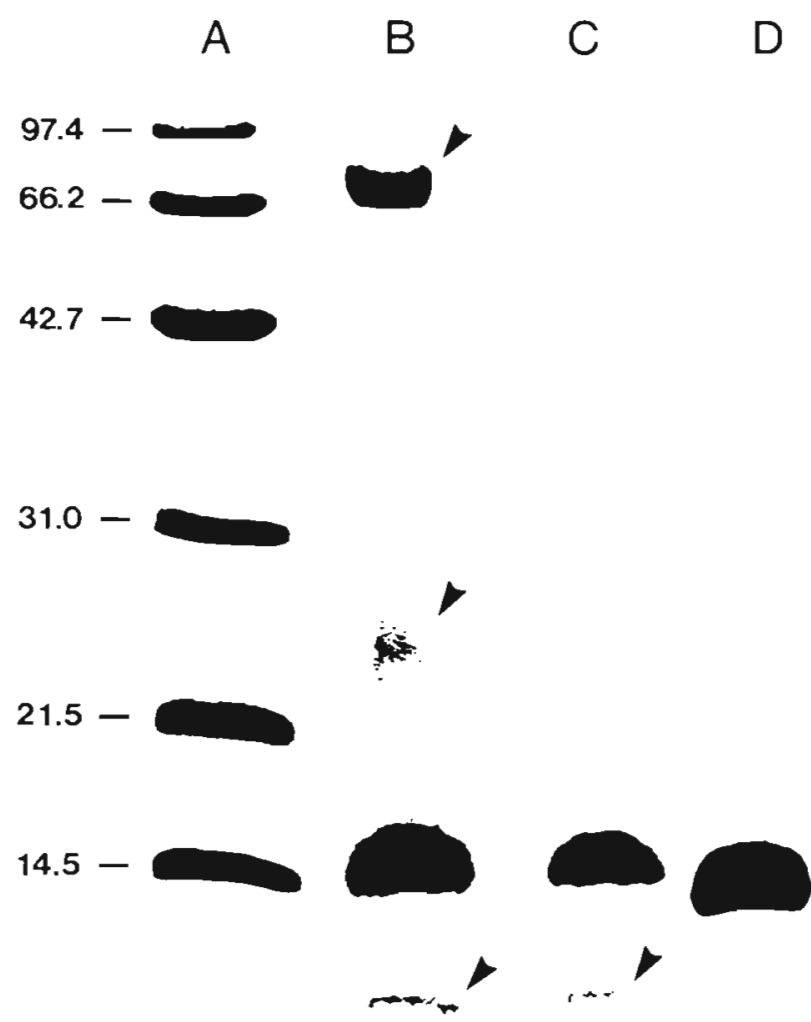

Fig. 3. SDS polyacrylamide electrophoretic patterns of (A) BioRad Low Molecular Weight Standards (phosphorylase b 97.4 $\mathrm{kD}$, bovine serum albumin $66.2 \mathrm{kD}$, ovalbumin $42.7 \mathrm{kD}$, carbonic anhydrase $31.0 \mathrm{kD}$, soybean trypsin inhibitor $21.5 \mathrm{kD}$, hen's egg-white lysozyme $14.5 \mathrm{kD}$ ); (B) partially purified coho egg lysozyme (arrows = protein contaminants); $(C)$ as for (B), but after boiling at $100^{\circ} \mathrm{C}$ for $20 \mathrm{~min}$ (supernatant); (D) purified coho egg lysozyme (fractions with lytic activity against Micrococcus lysodeikticus eluted from Sephadex G100 gel). $12.5 \%$ polyacrylamide gel stained with Coomassie R-250

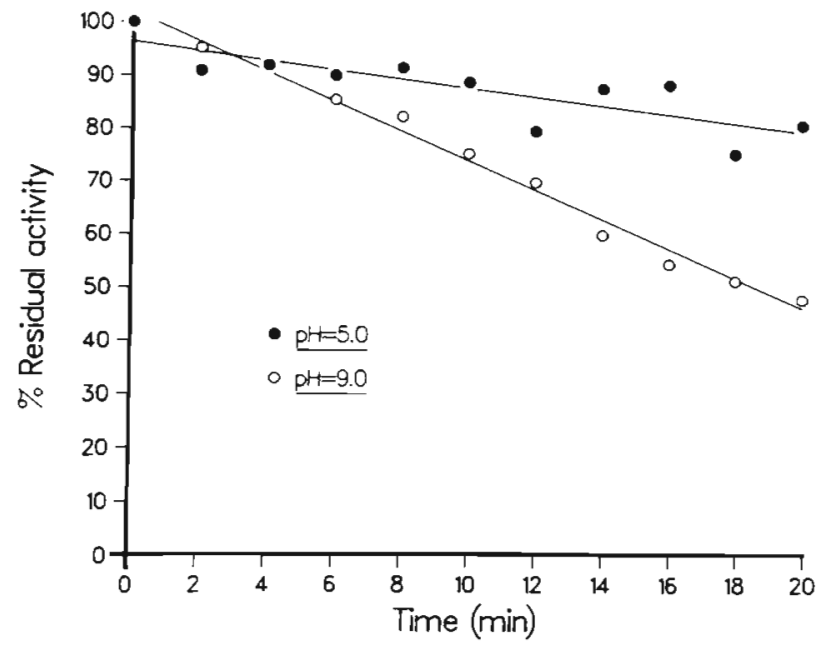

Fig. 4n Heat inactivation at $100^{\circ} \mathrm{C}$ of coho egg lysozyme at acidic and alkaline $\mathrm{pHs}$ 
proteins present in the lysozyme-containing cc-cellulose eluates (Fig. 3).

Some comments on the lysozyme purification procedure are warranted. SDS-PAGE of the PPL revealed the presence of at least 3 other proteins with molecular weights of 75,24 , and $<14.5 \mathrm{kD}$, all of which also readily adsorbed to cc-cellulose (Fig. 3). Tests on these proteins revealed that they possessed no lysozyme-like activity (data not shown). These contaminating proteins were successfully removed by gel filtration on Sephadex G-100 (Fig. 3, lane D). The typical elution pattern for the egg lysozyme on gel filtration is shown in Fig. 5. Lysozyme activity in the sample occurred in fractions 59 to 71 and was associated with a single protein of molecular weight (MW) $14.5 \mathrm{kD}$ (Fig. 3, lane D). This protein comesponds iv the classical type (ctype) lysozyme found in birds and mammals (Jolles \& Jolles 1984) as well as in fish kidneys (Lie et al. 1989).

The salmonid embryo has little or no ability to display specific immunity due to the immaturity of its lymphoid tissues (Ellis 1977). However, during the initial period of independent existence, young salmonids are protected by non-specific factors while their lymphoid immune system matures (Fletcher 1982, Tatner \& Manning 1985). Very young fish possess non-lymphoid defence factors such as macrophages and naturally occurring lysins and agglutinins (Fletcher 1982). In addition, other non-specific protective agents such as lectins and agglutinins have been reported from the eggs of several species of fish (Krajhanzl et al. 1978, Voss et al. 1978, Kudo \& Inoue 1986). These agents, along with lysozyme found in our study, may play a protective (antimicrobial) role in fish eggs and perhaps also in very young fish, the latter likely receiving their initial supply of lysozyme via the egg yolk.
The source of the lysozyme present in the eggs is unknown. It seems likely, however, that it is released from the kidneys and other lysozyme-rich tissues and transported to the developing eggs via the serum. Studies indicate that lysozyme activity is associated with tissues rich in leucocytes (kidney, spleen, alimentary tract). The leucocytes probably contribute to the serum lysozyme activity since their number increases concomitantly with serum lysozyme levels (Fletcher \& White 1973). Seasonal observations of lysozyme activity in fish serum indicate significant differences in the enzyme concentration in fish of different ages, the highest levels of the enzyme occurring in spawners (Studnicka et al. 1986). In salmonids, the coelomic fluid of the brood females may become infected with high concentrations of bacteria during the spawning season. This fluid bathes the eggs following ovulation and certain of the contained microbes may find their way into the eggs via the micropyle and be transmitted to the progeny (Evelyn et al. 1984).

Lysozyme, alone or in conjunction with complement and antibody, is thought to contribute to bacteriolytic mechanisms in vertebrates, including fish (Vladimirov 1968, Glynn 1969). However, we cannot yet ascribe a function to the lysozyme found in coho eggs. The occurrence of the enzyme in such high concentrations outside the digestive tract, as well as its close association with cells of the immune system, strongly suggest that it has an important defensive function. Previous work on lysozyme from rainbow trout has shown that the enzyme has a substantial antibacterial activity not only against Gram-positive bacteria but also against Gram-negative bacterial fish pathogens (Grinde 1989). The presence of the enzyme in eggs may explain why only certain bacterial fish pathogens are transmitted

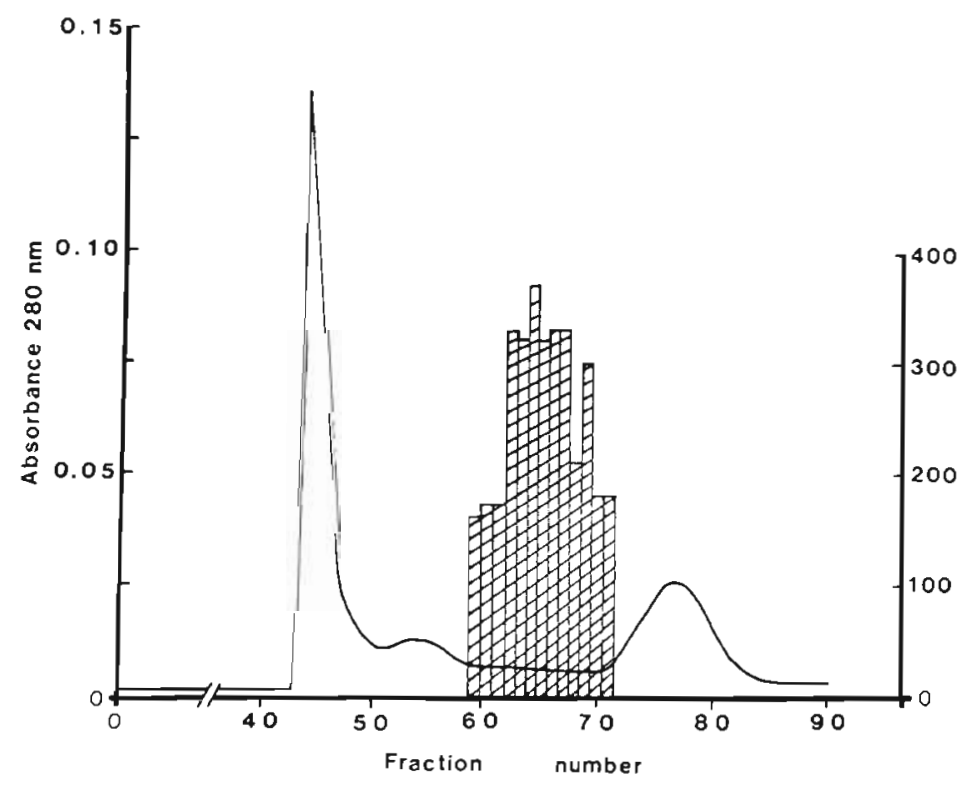

Fig. 5. Gel filtration on Sephadex G-100 of $2 \mathrm{ml}$ of partially purified lysozyme (PPL). Fractions $(0.5 \mathrm{ml})$ were eluted at $30 \mathrm{ml} \mathrm{h}^{-1}$ from a column $25 \times 1.5 \mathrm{~cm}$, with $0.06 \mathrm{M}$ phosphate buffer $(\mathrm{pH}$ $6.0)$ containing $0.02 \mathrm{M} \mathrm{NaCl}$, at room temperature. Lysozyme activity located in fractions 59 to 71 (indicated on histogram). The continuous line shows the absorption at $280 \mathrm{~nm}$ of the eluted fractions 
from parent to progeny within eggs. This question is now being investigated.

Acknowledgement. A. N. Yousif was in receipt of a scholarship from the government of the Sudan. This research was partially supported by a Natural Sciences and Engineering Research Council of Canada operating grant to L.J.A.

\section{LITERATURE CITED}

Ellis, A. E. (1977). Ontogeny of the immune response in Salmo salar. Histogenesis of the lymphoid organs and appearance of membrane immunoglobulin and mixed leucocyte reactivity. In: Solomon, J. B., Horton, J. D. (eds.) Developmental immunology. Elsevier/North Holland Biomedical Press, Amsterdam, p. 225-231

Evelyn, T. P. T., Ketcheson, J. E., Prosperi-Porta, L. (1984). Further evidence for the presence of Renibacterium salmoninarum in salmonid eggs and for the failure of povidone-iodine to reduce the intra-ovum infection rate in water-hardened eggs. J. Fish Dis. 7: 173-182

Fange, R., Lundblad, G., Lind, L. (1976). Lysozyme and chitinase in the blood and lymphomyeloid tissues of marine fish. Mar. Biol. 36: 277-282

Fletcher, T. C. (1982). Non-specific defence mechanisms of fish. Dev. Comp. Immunol. 2: 123-132

Fletcher, T. C., White A. (1973). Lysozyme activity in the plaice (Pleuronectes platessa L.). Experientia 29: 1283-1285

Fletcher, $\Upsilon$. C., White A. (1976). The lysozyme of the plaice (Pleuronectes platessa L.). Comp. Biochem. Physiol. 55 B: 207-210

Glynn, A. A. (1969). The complement lysozyme sequence in immune bacteriolysis. Immunology 16: 463-471

Grinde, B. (1989). Lysozyme from rainbow trout (Salmo gairdneri) as an antibacterial agent against fish pathogens. J. Fish Dis. 12: 95-104

Grinde, B., Jolles, J., Jolles, P. (1988). Purification and characterization of two lysozymes from rainbow trout (Salmo gairdneri). Eur. J. Biochem. 173: 269-273

Imoto, T., Hayashi, K., Funatsu, M. (1968). Characterization of enzyme-substrate complex of lysozyme I. Two types of complex. J. Biochem. 64: 387-392

Imoto, T., Johnson, L. N., North, A. C. T., Phillips, D. C., Rupley, J. A. (1972). Vertebrate lysozymes. In: Boyer, P. D. (ed.) The enzymes. 3rd edn, Vol. 7. Academic Press, New York, p. 665-868

Editional responsibility: Managing Editor
Imoto, T., Yagishita, K. (1973). Chitin coated cellulose as an adsorbent of lysozyme-like enzymes. Preparation and properties. Agric. biol. Chem. 37: 465-470

Jolles, P. (1969). Lysozymes: a chapter of molecular biology. Angew. Chem. int. Ed. Engl. 8: 227-239

Jolles, P., Jolles, J. (1984). What's new in lysozyme research? Always a model system, today as yesterday. Mol. Biochem. 63: $165-189$

Krajhanzyl, A., Horejsi, V., Kocourek, J. (1978). Isolation, partial characterization and comparison of lectins from the roe of five fish species. Biochem. biophys. Acta 532: $215-224$

Kudo, S., Inoue, M. (1986). A bactericidal effect of fertilization envelope extract from fish eggs. Zool. Sci. 3: 323-329

Laemmli, U. K. (1970). Cleavage of structural proteins during the assembly of the head of bacteriophage T4. Nature, Lond. 227: 680-685

Lie, Ø., Evensen, Ø., Sorensen, A., Froysadal, E. (1989). Study on lysozyme activity in some fish species. Dis. aquat. Org 6: $1-5$

Lie, Ø., Syed, M. (1986). Some properties of the lysozymes in serum and colostrum from cows with high and low lytic power against Micrococcus lysodeikticus. Anim. Genet. 17: $47-59$

Lindsay, G. J. H. (1986). The significance of chitinolytic enzymes and lysozyme in rainbow trout Salmo gairdneri defence. Aquaculture 51. 169-173

McHenery, J. G., Birkbeck T. H, Allen J. A. (1979). The occurrence of lysozyme in marine bivalves. Comp Biochem. Physiol. 63B: 25-28

Osserman, E. F., Canfield, R. E., Beychok, S. (1974) Lysozyme. Academic Press, New York

Salton, M. R. J. (1957). The properties of lysozyme and its action on microorganisms. Bact. Rev. 21-82-99

Sankaran, K., Gurnani, S. (1972). On the variation in the catalytic activity of lysozyme in fishes. Ind. J. Biochem Biophys. 9: 162-165

Studnicka, M., Siwicki, A., Ryka, B. (1986). Lysozyme level in carp (Cyprinus carpio L.) Bamidgeh 38:(1) 22-25

Tatner, M. F., Manning, M. J. (1985). The ontogenic development of the reticuloendothelial system in the rainbow trout, Salmo gairdneri Richardson. J. Fish Dis. 8: 35-41

Vadimirov, V. L. (1968). Immunity in fish. Bull. Off. int. Epiz. 69: $(9-10)$ 1365-1372

Voss, E. W., Fryer, J. L., Banowetz, G. M. (1978). Isolation, purification, and partial characterization of a lectin from chinook salmon ova. Arch. Biochem. Biophy. 186: (1) $25-34$

Manuscript first received: June 21, 1990

Revised version accepted: October 25, 1990 